\title{
Prevention of catheter-associated urinary tract infection: implementation strategies of international guidelines ${ }^{1}$
}

\author{
Vera Lúcia Fonseca Andrade ${ }^{2}$ \\ Filipa Alexandra Veludo Fernandes 3
}

Objective: to describe strategies used by health professionals on the implementation of the Centers for Disease Control and Prevention guidelines for the prevention of urinary infection

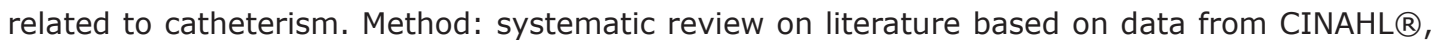
Nursing \& Allied Health Collection, Cochrane Plus Collection, MedicLatina, MEDLINE $®$, Academic Search Complete, ACS - American Chemical Society, Health Reference Center Academic, Nursing Reference Center, ScienceDirect Journals and Wiley Online Library. A sample of 13 articles was selected. Results: studies have highlighted the decrease of urinary tract infection related to catheterism through reminder systems to decrease of people submitted to urinary catheterism, audits about nursing professionals practice and bundles expansion. Conclusion: the present review systemizes the knowledge of used strategies by health professionals on introduction to international recommendations, describing a rate decrease of such infection in clinical practice.

Descriptors: Urinary Tract Infections; Urinary Catheterization; Nursing.

\footnotetext{
1 Paper extracted from master thesis "Prevenção da infecção associada a cuidados de saúde: um olhar sobre o papel da enfermagem", presented to Instituto de Ciencias da Saúde, Universidade Católica Portuguesa, Lisboa, Portugal.

2 MSc, Assistant Professor, Escola Superior Politécnica de Saúde, Instituto de Ciências da Saúde, Universidade Católica Portuguesa, Lisboa, Portugal.

3 MSc, RN, Unidade de Cuidados Intensivos, Centro Hospitalar Barreiro Montijo, EPE, Barreiro, Portugal.
}

Andrade VLF, Fernandes FAV. Prevention of catheter-associated urinary tract infection: implementation strategies of international guidelines. Rev. Latino-Am. Enfermagem. 2016;24:e2678. [Access ]; Available in: DOI: http://dx.doi.org/10.1590/1518-8345.0963.2678. 


\section{Introduction}

Catheter-associated urinary tract infection (CAUTI) is frequent on hospitalized people. On infections associated to health care, catheter-associated urinary tract infection corresponds to $40 \%{ }^{(1)}$ About $15 \%$ to $25 \%$ of hospitalized people are submitted to vesical catheterization $^{(2)}$. In most cases, this technique is used without proper indication, extending its unnecessary use. CAUTI is referred to in several studies about increase on mortality and morbidity, as well as hospitalization, and, consequently, associated $\operatorname{costs}^{(2)}$.

However, it is pointed out that when compared to other healthcare-associated infections (HAI), urinary tract infection (UTI) presents a low morbidity. A study carried out in the USA ${ }^{(2)}$ determined that UTI rate was superior to 560 thousands when compared to other HAIs, with a mortality rate of $2.3 \%$, and bacteriuria (which develop bactareamia) cases lower than $5 \%$. UTI is the main cause of infecctions on secondary nosocomial bloodstream, about $17 \%$ of nosocomial bactareamia origin from urinary, with an associated mortality of $10 \%$. Society for Healthcare Epidemology of America (SHEA) estimates between $17 \%$ and $69 \%$ of CAUTI can be prevented through infection control recommendations, based on evidences ${ }^{(2)}$

The investigation suggests that CAUTI prevention goes through recommended actions, and based on evidences that lower the rate for this infection. Simple initiatives as hand hygiene, use of a reliable technique, maintenance and the way the catheter is removed can contribute to prevent the associated infection. An unnecessary urinary catheterism and the period of permanency of catheter influence the infection development, being modifiable factors ${ }^{(2)}$. Currently, the practice based on evidences is a highlight in a culture that aims a quality standard for safe care. However, it is pointed out that many times professionals face a few embarrassments regarding the connection between results from the most current and practical investigation.
The way actions and/or strategies are applied for implementations, in one document, providing practical changeable tools to readers, based in measurable results. This systematic review supplies the answer to this need, gathering the scattered knowledge on literature and facilitating the access to safe practices based on evidences. The study's goal was to search evidences regarding strategies that health professionals found out on practice to apply/implement of CDC recommendations and CAUTI prevention.

\section{Method}

The structure of this systematic review on literature was based on the CAUTI thematic, elaborating the initial question, defining eligibility criteria, selecting article samples and further analysis and results discussion. To obtain the answer to the initial question "What are the strategies health professionals use for implementing the Centers for Disease Control and prevention (CDC) guidelines for CAUTI prevention?". A systematic review of the literature was made to reach this goal.

As a research strategy, the following health descriptors were used: urinary AND infection AND catheter AND nurs*. To find answers to this question, the goal was to perceive how nurses operationalized the recommendations of the Centers for Disease Control and prevention on praxis and intervention on CAUTI prevention.

The temporal limit of research was from January 2007 to December 2014, for fully available papers, as a way to contextualize the thematic in the past seven years. The databases used were $\mathrm{CINAHL}^{\circledR}$, Nursing \& Allied Health Collection, Cochrane Plus Collection, MedicLatina, MEDLINE ${ }^{\circledR}$, Academic Search Complete, ACS - American Chemical Society, Health Reference Center Academic, Nursing Reference Center, ScienceDirect Journals, and Wiley Online Library. Face to the studied phenomenon, the eligibility criteria were established according to Figure 1.

\begin{tabular}{|c|c|c|}
\hline Selection Criteria & Inclusion Criteria & Exclusion Criteria \\
\hline Participants & Hospitalized people submitted to vesical \\
catheterization & $\begin{array}{c}\text { People submitted to chronic vesical } \\
\text { catheterization }\end{array}$ \\
\hline Intervention & $\begin{array}{c}\text { Strategies for the implementation of the Centers } \\
\text { for Disease Control and Prevention guidelines } \\
\text { for urinary tract infections associated to } \\
\text { catheterism }\end{array}$ & $\begin{array}{c}\text { Guidelines review; usage of materials on control } \\
\text { and prevention of catheterization-associated } \\
\text { urinary tract infections; administration of } \\
\text { antibiotherapy on prevention of urinary tract } \\
\text { infection }\end{array}$ \\
\hline Results & $\begin{array}{c}\text { Number of vesical catheterization, duration of } \\
\text { vesical catheterization, urinary tract infection } \\
\text { rate associated to catheterism }\end{array}$ & $\begin{array}{c}\text { Guidelines implementation without evaluation } \\
\text { of its impact }\end{array}$ \\
\hline
\end{tabular}




\begin{tabular}{|c|c|c|}
\hline Selection Criteria & Inclusion Criteria & Exclusion Criteria \\
\hline Draw & Primary studies with quantitative approach & $\begin{array}{c}\text { Opinion studies, primary studies with qualitative } \\
\text { approach. }\end{array}$ \\
\hline
\end{tabular}

Figure 1 - Inclusion and exclusion criteria

We would like to highlight that the exclusion of articles was also related to lack of information about parameters considered important for the analysis; participants, interventions, results, study's draw. Facing the studies' diversity and non-relevance to the investigation question, the parameter Comparison [C] was removed. We also considered, when selecting the studies, the bibliographic references mentioned ${ }^{(3)}$ On the initial phase, 92 articles were obtained, from which, 38 were excluded by their titles. After reading 53 abstracts, 29 articles were rejected. Twenty-five articles were fully analyzed, from which 12 were rejected, according the inclusion/exclusion criteria, leading to 13 articles selected to perform the systematic review on literature. Figure 2 is a flowchart of the mentioned article selection.

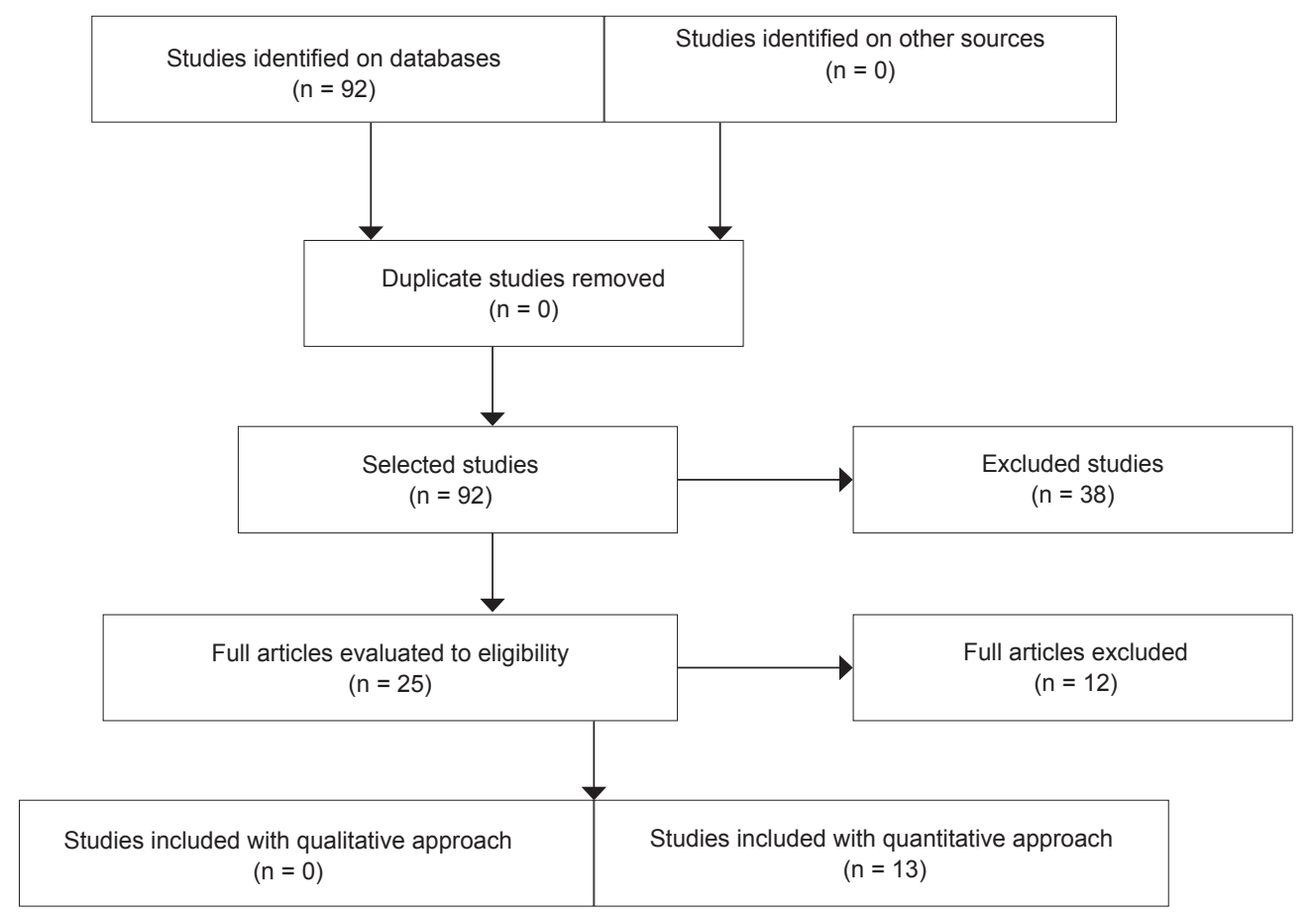

Figure 2 - Flowchart of articles selection

Afterwards, the articles were classified in accordance to evidence level (4), determining that most of the selected articles presented a high level of evidence, considering about $70 \%$ are on evidence level Ib. On evidence level Ib, the scientific evidence comes from, at least, a random clinical trial. Following two articles placed on evidence level IIa, and two articles on level Ia, the last one being the higher evidence level(4). On level IIa, the evidence was obtained through a forward study controlled and well designed, without randomization. On level Ia, the scientific evidence obtains through a met-analysis of random clinical trials. The 13 selected articles, according the evidence level, are presented on Figure 3. 


\begin{tabular}{|c|c|c|}
\hline \multicolumn{2}{|c|}{ Evidence level(4) } & Selected articles \\
\hline Ia & $\begin{array}{c}\text { Evidence obtained through meta-analysis of randomized } \\
\text { and controlled clinical trials }\end{array}$ & Winter et al, 2009; Mori, 2014. \\
\hline Ib & $\begin{array}{c}\text { Evidence obtained through, at least, a randomized and } \\
\text { controlled clinical trial }\end{array}$ & $\begin{array}{c}\text { Crouzet et al, 2007; Weitzel et al, 2008; Apisarnthanarak et al 2007; Loeb } \\
\text { et al 2008; Rhodes et al, 2009; Gokula et al 2012; Oman et al 2012; Dailly, } \\
\text { 2012; Chen et al, 2013. }\end{array}$ \\
\hline Ila & $\begin{array}{r}\text { Evidence obtained through, at least, one well controlled } \\
\text { study without randomization }\end{array}$ & Fakih et al 2008; Elpern et al 2009. \\
\hline IIb & $\begin{array}{c}\text { Evidence obtained through, at least, another study well } \\
\text { designed, almost experimental. }\end{array}$ & Studies have not been found \\
\hline III & $\begin{array}{c}\text { Evidence obtained through descriptive studies non- } \\
\text { experimental, as comparative studies, correlative, and } \\
\text { clinical cases }\end{array}$ & Studies have not been found \\
\hline IV & $\begin{array}{c}\text { Evidence obtained through experts reports, opinions } \\
\text { and/or clinical experiences from respectful authorities. }\end{array}$ & Stund \\
\hline
\end{tabular}

Figure 3 - Rating of selected articles, according to evidence level

\section{Results}

The results are presented in table, with the analysis of studies selected to review literature, specifying each one according to author, year, country, participants, interventions, results and design (Figure 4). We made a detailed analysis of these factors regarding their contribution to the answer to the investigation question.

\begin{tabular}{|c|c|c|c|c|}
\hline $\begin{array}{c}\text { Author(s) } \\
\text { Year/Country }\end{array}$ & Participants & Interventions & Results & Design \\
\hline $\begin{array}{l}\text { Crouzet et al., } 2007 \\
\quad(\text { France })^{(5)}\end{array}$ & $\begin{array}{l}\text { Two hundred and thirty- } \\
\text { four clients submitted } \\
\text { to urinary catheterism } \\
\text { from several services } \\
\text { on Besançon Hospial, } \\
\text { between January } 1 \text { and } \\
\text { June } 30,2005 \text {. }\end{array}$ & $\begin{array}{l}\text { The nurse reminds the doctor on } \\
\text { a daily basis about the urinary } \\
\text { catheter removal in people } \\
\text { with more than four days of } \\
\text { catheterization }\end{array}$ & $\begin{array}{l}\text { Decrease on catheterization } \\
\text { duration non-significant } \\
(p=0.14) \text {; however there were } \\
\text { a significant decrease on } \\
\text { orthopedic and cardiology } \\
\text { services. Urinary tract infection } \\
\text { incidence associated to } \\
\text { catheterism has significantly } \\
\text { decreased ( } p=0.03) \text {. }\end{array}$ & Quantitative study \\
\hline $\begin{array}{l}\text { Apisarnthanarak et al., } \\
2007 \\
\text { (Thailand) }^{(6)}\end{array}$ & $\begin{array}{l}\text { Two thousand four } \\
\text { hundred and twelve } \\
\text { clients admitted on Thai } \\
\text { Hospital ( } 450 \text { beds), } \\
\text { submitted to vesical } \\
\text { catheterism, between } \\
\text { July } 1,2004 \text {, and June } \\
30,2006 \text {. }\end{array}$ & $\begin{array}{l}\text { Daily, nurses remind doctors about } \\
\text { the removal of unneeded urinary } \\
\text { catheters, in accordance with } \\
\text { indications based on evidences, } \\
\text { and after three days of insertion of } \\
\text { the catheter. }\end{array}$ & $\begin{array}{l}\text { Catheterization duration has } \\
\text { decreased, approximately } \\
\text { seven days }(p<0.001) \text {; } \\
\text { unnecessary catheterization } \\
\text { decreased in } 9.4 \%(p=0.04) \text {. } \\
\text { Catheter-associated urinary } \\
\text { tract infection rate has } \\
\text { decreased } 75 \%(p<0.001) ; \\
\text { hospital costs decreased } 58 \% \\
\text { (p<0.001); and costs with } \\
\text { antibiothrapy decreased } 63 \% \\
(p<0.001) \text {. }\end{array}$ & Quantitative study \\
\hline $\begin{array}{c}\text { Fakih et al., } 2008 \\
(\text { USA })^{(7)}\end{array}$ & $\begin{array}{l}\text { Twelve surgery medical } \\
\text { units from an university } \\
\text { hospital; } 608 \text { beds; } \\
\text { from May, } 2006 \text { to April, } \\
2007 . \\
\text { Four thousand, nine } \\
\text { hundred and sixty three } \\
\text { clients were observed. }\end{array}$ & $\begin{array}{l}\text { A nurse-led participates of the } \\
\text { multidisciplinary daily visit and } \\
\text { discuss the need for urinary } \\
\text { catheter and its early removal. }\end{array}$ & $\begin{array}{l}\text { The usage of vesical } \\
\text { catheterism decreased } 20 \% \\
\qquad(p=0.002) ; \\
\text { Unnecessary usage of vesical } \\
\text { catheterism decreased } 38 \% \text {. }\end{array}$ & Quantitative study \\
\hline $\begin{array}{l}\text { Loeb et al., } 2008 \\
\qquad(\text { USA })^{(8)}\end{array}$ & $\begin{array}{l}\text { Six hundred and ninety } \\
\text { two people hospitalized } \\
\text { in a Canadian Hospital } \\
\text { submitted to vesical } \\
\text { catheterism during } 48 \\
\text { hours, at least. }\end{array}$ & $\begin{array}{l}\text { With indication on prescribed } \\
\text { clinical process to suspend } \\
\text { vesical catheterization in people } \\
\text { submitted to this technique. Nurses } \\
\text { were autonomous in making } \\
\text { decisions about the need of } \\
\text { urinary catheterism; unnecessary } \\
\text { urinary catheters were removed by } \\
\text { nurses, and this decision making } \\
\text { process was based on scientific } \\
\text { investigation. }\end{array}$ & $\begin{array}{l}\text { Catheterization duration has } \\
\text { decreased about } 1.34 \text { day } \\
\qquad(p<0.001) \text {. } \\
\text { Duration of unnecessary } \\
\text { catheterization decreased } \\
\text { about } 1.69 \text { day }(p<0.001) \text {. } \\
\text { Lightly significant decrease on } \\
\text { catheter-associated urinary } \\
\text { tract infection rate }(p=0.71)\end{array}$ & Quantitative study \\
\hline
\end{tabular}




\begin{tabular}{|c|c|c|c|c|}
\hline $\begin{array}{l}\text { Weitzel et al., } 2008 \\
\qquad(\text { USA })^{(9)}\end{array}$ & $\begin{array}{l}\text { Fifty clients submitted to } \\
\text { urinary catheterism by } \\
\text { the medical service }\end{array}$ & $\begin{array}{l}\text { Use of protocol by nursing team } \\
\text { who daily checks if the urinary } \\
\text { catheterization is still required. In } \\
\text { case the indication is not clearly } \\
\text { justified, the urinary catheter is } \\
\text { removed without medical indication. }\end{array}$ & $\begin{array}{c}\text { Percentage of clients who } \\
\text { developed catheter-associated } \\
\text { urinary tract infection } \\
\text { Pre-test: } 37 \\
\text { Post-test: } 6.7 \\
\text { Average of days in which } \\
\text { clients were submitted to } \\
\text { urinary catheterism: } \\
\text { Pre-test: } 8.6 \\
\text { Post-test: } 4.5\end{array}$ & Quantitative study \\
\hline $\begin{array}{l}\text { Elpern et al., } 2009 \\
(\text { USA })^{(10)}\end{array}$ & $\begin{array}{l}\text { Three hundred and } \\
\text { thirty seven hospitalized } \\
\text { clients on the ICU of } \\
\text { the Chicago Hospital, } \\
\text { submitted to urinary } \\
\text { catheterism between } \\
\text { December 1, 2007, and } \\
\text { May 31, 2008 }\end{array}$ & $\begin{array}{l}\text { The clients submitted to urinary } \\
\text { catheterism were daily assigned } \\
\text { in a database by nursing team } \\
\text { with the respective catheterization } \\
\text { indication. The clients with } \\
\text { inappropriate catheterization } \\
\text { indications were identified by } \\
\text { the nursing team, and through } \\
\text { investigation data, they analyzed } \\
\text { with doctors the need for urinary } \\
\text { catheterism. }\end{array}$ & $\begin{array}{c}\text { The incidence of the catheter- } \\
\text { associated urinary tract } \\
\text { infection decreased from } \\
4.7 / 100 \text { catheters by day, to } \\
\text { zero. } \\
\text { Decrease on the } \\
\text { catheterization duration from } \\
311.7 \text { days by month to } 238.6 \\
\text { days by month }(p<0.001) \text {. }\end{array}$ & Quantitative study \\
\hline $\begin{array}{l}\text { Winter et al., } 2009 \\
\text { (USA) })^{(11)}\end{array}$ & $\begin{array}{c}\text { Clients of the Heart } \\
\text { Hospital Baylor submitted } \\
\text { to urinary catheterism } \\
\text { during six months }\end{array}$ & $\begin{array}{c}\text { Baylor Nurses's Bundle on prevention } \\
\text { of catheter-associated urinary tract } \\
\text { infection. Bundles applications, such as: } \\
\text { to avoid urinary catheterism, urinary } \\
\text { catheterism only when needed, hands } \\
\text { hygiene, use of aseptic techniques on } \\
\text { catheter insertion, and maintenance, } \\
\text { based on the best scientific evidence. }\end{array}$ & $\begin{array}{c}\text { Reduction on the catheter- } \\
\text { association urinary tract infection } \\
\text { incidence was } 88 \%\end{array}$ & Quantitative study \\
\hline $\begin{array}{l}\text { Rhodes et al., } 2009 \\
\left(_{(U S A)}\right)^{(12)}\end{array}$ & $\begin{array}{l}\text { Clients from the Baylor } \\
\text { Specialty Hospital } \\
\text { submitted to urinary } \\
\text { catheterism during six } \\
\text { months }\end{array}$ & $\begin{array}{l}\text { To limit urinary catheterism duration, } \\
\text { initial formation through bundles to } \\
\text { all nurses about proper indications } \\
\text { to urinary catheterism, and catheter } \\
\text { maintenance, daily evaluation of the } \\
\text { need to urinary catheterism made by } \\
\text { nurses. } \\
\text { Creation of Baylor Nurses's Algorithm } \\
\text { to assess urethral Catheter Need. }\end{array}$ & $\begin{array}{l}\text { Decrease of catheter- } \\
\text { associated urinary tract } \\
\text { infection in } 5 \% \text {. }\end{array}$ & Quantitative study \\
\hline $\begin{array}{l}\text { Gokula et al., } \\
\qquad 2012 \\
\text { (USA) }^{(13)}\end{array}$ & $\begin{array}{l}\text { Two hundred and eighty } \\
\text { hospitalized clients } \\
\text { were submitted to } \\
\text { urinary catheterism on } \\
\text { the Medical Academic } \\
\text { Center of Midwest ( } 319 \\
\text { beds: includes medical } \\
\text { surgery units, ICUs, } \\
\text { rehabilitation unit, and } \\
\text { surgery and emergency } \\
\text { unit) }\end{array}$ & $\begin{array}{l}\text { A team formed by doctors, a professor } \\
\text { nurse, an infection control nurse, a } \\
\text { nurse specialist on rehabilitation, and } \\
\text { a nurse specialist on emergency. The } \\
\text { creation of a performing protocol with } \\
\text { the following stages; } \\
\text { Identify, assessing, implementing, } \\
\text { modifying/maintaining and spreading/ } \\
\text { surveillance - to guide the project. } \\
\text { The Foley Insertion Removal } \\
\text { Maintenance protocol consisted on } \\
\text { a verification list for catheterization, } \\
\text { catheterization maintenance, and } \\
\text { removal order. } \\
\text { During the process, a nurse-driven } \\
\text { system was included to verify lists, as } \\
\text { well as a reminder system to catheter } \\
\text { removal. }\end{array}$ & $\begin{array}{l}\text { Urinary tract infection rate: } \\
2.21 / 1,000 \text { patients per day } \\
\text { (from January to April, 2007); } \\
\text { Urinary tract infection } \\
\text { associated to health care } \\
\text { rate: } 0.87 \text { in } 1.000 \text { patients/ } \\
\text { day (November to December, } \\
2009 \text { ); } \\
\text { Catheter-associated urinary } \\
\text { tract infection: } 0.435 \text { in } 1,000 \\
\text { patients/day (2011) }\end{array}$ & Quantitative study \\
\hline $\begin{array}{l}\text { Oman et al., } 2012 \\
(\text { USA })^{(14)}\end{array}$ & $\begin{array}{l}\text { A hundred and fifty } \\
\text { clients submitted to } \\
\text { urinary catheterism } \\
\text { in a Surgery unit, and } \\
125 \text { clients submitted } \\
\text { to urinary catheterism } \\
\text { in a Pulmonology } \\
\text { unit - Hospital of the } \\
\text { University of Colorado }\end{array}$ & $\begin{array}{l}\text { Intervention from a nurse-driven, } \\
\text { who absorbs the scientific evidence } \\
\text { in practice, taking into consideration } \\
\text { the most recent recommendations, } \\
\text { Phase 1: data collection about } \\
\text { practice alterations and rate of } \\
\text { catheter-associated urinary tract } \\
\text { infection. } \\
\text { Phase 2: House wide intervention, } \\
\text { which constituted a review } \\
\text { on hospital policies regarding } \\
\text { insertion and attention to urinary } \\
\text { catheter, conformity evaluation } \\
\text { with recommended practices of } \\
\text { competence and insertion training } \\
\text { and maintenance of the catheter, } \\
\text { and evaluation of used products on } \\
\text { urinary catheterization }\end{array}$ & $\begin{array}{c}\text { Decrease on catheter duration } \\
\text { on different phases from } 1 \text { to } 3 \\
\text { - on Surgery Unit there was a } \\
\text { significant decrease ( } p=0.018) \text {; } \\
\text { Catheter-associated } \\
\text { urinary tract infection rate: } \\
\text { Pulmonology Unit has zero } \\
\text { incidence before intervention, } \\
\text { and kept this same incidence; } \\
\text { The Surgery Unit has increased } \\
\text { the catheter-associated urinary } \\
\text { tract infection incidence on } \\
\text { phase } 1 \text { to phase } 2 \text {, and then } \\
\text { decreased the incidence } \\
\text { on phase } 3.96 \% \text { of nurses } \\
\text { concluded the training. }\end{array}$ & Quantitative study \\
\hline
\end{tabular}




\begin{tabular}{|c|c|c|c|c|}
\hline $\begin{array}{c}\text { Dailly, } 2012 \\
\text { (United Kingdom) }^{(15)}\end{array}$ & $\begin{array}{l}\text { Four hundred clients } \\
\text { from the Royal } \\
\text { Hampshire Hospital } \\
\text { submitted to urinary } \\
\text { catheterism in June, } \\
2009\end{array}$ & $\begin{array}{l}\text { Building a document - Urinary } \\
\text { Catheter Assessment and } \\
\text { Monitoring form - the nurse } \\
\text { evaluated and documented the } \\
\text { need for urinary catheter and } \\
\text { its maintenance. The practices } \\
\text { performed were registered, in } \\
\text { accordance with the guidelines and } \\
\text { the need to keep the catheter, and } \\
\text { upon this, to expose to the assistant } \\
\text { doctor the indication to keep or not } \\
\text { the urinary catheter. }\end{array}$ & $\begin{array}{l}\text { Significant improvement on the } \\
\text { technical quality of insertion } \\
\text { and maintenance of vesical } \\
\text { catheterism, when compared to } \\
\text { previous records about Urinary } \\
\text { Catheter Assessment and } \\
\text { Monitoring form application. } \\
\text { There has been an increase } \\
\text { on audits by month to } \\
\text { clients submitted to urinary } \\
\text { catheterism, being removed } \\
\text { those deemed unnecessary } \\
\text { after audit. }\end{array}$ & Descriptive study \\
\hline $\begin{array}{l}\text { Chen et al., } 2013 \\
\quad \text { (Taiwan) }^{(16)}\end{array}$ & $\begin{array}{l}\text { Study performed } \\
\text { in two Respiratory } \\
\text { Intensive Care units. } \\
\text { The incidence upon two } \\
\text { hundred and seventy } \\
\text { eight users submitted } \\
\text { to vesical catheterism } \\
\text { for more than three } \\
\text { days, between May and } \\
\text { November, } 2008 \text {. }\end{array}$ & $\begin{array}{l}\text { Development of a reminder system } \\
\text { through a usage record of proper } \\
\text { or not usage of urinary catheter. } \\
\text { Such indications has as basis the } \\
\text { guidelines emanated by Centers for } \\
\text { Disease Control and Prevention, } \\
\text { Society for } \\
\text { Healthcare Epidemiology of } \\
\text { America e Infectious } \\
\text { Diseases Society of America. The } \\
\text { reminder systems evaluated the } \\
\text { viability to catheter removal (on } \\
\text { users submitted to this technique } \\
\text { for, at least, seven days) There } \\
\text { was an intervention group (with } \\
\text { reminder system), and a control } \\
\text { group (without a reminder system). } \\
\text { The investigative nurse evaluated } \\
\text { and identified users with vesical } \\
\text { catheterism on daily basis, and } \\
\text { in case there was no indication, } \\
\text { the nurse responsible for the user } \\
\text { was informed, and the doctor } \\
\text { was reported about the catheter } \\
\text { removal. }\end{array}$ & $\begin{array}{l}\text { Usage rate of urinary catheter } \\
\text { decreased } 22 \% \text { on intervention } \\
\text { group, when compared to } \\
\text { control group. Decrease of } \\
\text { average catheterism duration. } \\
\text { The reminder intervention } \\
\text { has decreased the catheter- } \\
\text { associated urinary tract } \\
\text { infection incidence in } 48 \% \text { on } \\
\text { intervention group, regarding } \\
\text { the control group. }\end{array}$ & Quantitative study \\
\hline $\begin{array}{l}\text { Mori, } 2014 \\
(\text { USA })^{(17)}\end{array}$ & $\begin{array}{l}\text { Study performed in a } \\
\text { community hospital } \\
\text { with } 150 \text { beds. All } \\
\text { hospitalized users } \\
\text { who were submitted } \\
\text { to vesical catheterism } \\
\text { during hospitalization. } \\
\text { The users from the } \\
\text { obstetric area were } \\
\text { excluded. }\end{array}$ & $\begin{array}{l}\text { A clinical nurse specialist led a } \\
\text { team of expert nurses, elements } \\
\text { of infection control commission, } \\
\text { and doctors, to the development } \\
\text { of a practical guideline protocol } \\
\text { based on the guidelines of the } \\
\text { Centers for Diasease Control } \\
\text { and Prevention de 2009, for the } \\
\text { need of urinary catheter, as well } \\
\text { as the maintenance record of } \\
\text { urinary catheterism. This protocol } \\
\text { allowed nurses to make decisions } \\
\text { autonomously regarding the } \\
\text { interruption of catheterism in case } \\
\text { proper indications were not known } \\
\text { and/or not justified. The nurses } \\
\text { obtained training about guidelines } \\
\text { for a month, implementing it } \\
\text { after Indwelling Urinary Catheter } \\
\text { Removal Protocol. }\end{array}$ & $\begin{array}{c}\text { Pre-intervention ( } \mathrm{n}=389) \text { : } \\
\text { No. of days under catheterism: } \\
1,280 ; \\
\text { Catheterism incidence: } 37.6 \% ; \\
\text { catheter-associated urinary } \\
\text { tract infection: } 0.77 \% \text {. } \\
\text { Post-intervention (three months } \\
\text { later) }(\mathrm{n}=282) \text { : } \\
\text { No. of days under catheterism: } \\
1,025 ; \\
\text { Catheterism incidence: } 27.7 \% \text {; } \\
\text { and catheter-associated urinary } \\
\text { tract infection: } 0.35 \% .\end{array}$ & Quantitative study \\
\hline
\end{tabular}

Building a document - Urinary Catheter Assessment and or urinary catheter and its maintenance. The practices formed were registered, in ed to keep the catheter, and the indication to keep or not

evelopment of a reminder system through a usage record of proper or not usage of urinary catheter. indications has as basis the Disease Control and Prevention, Ithcare Epidemiology of America e Infectious Ases Society of America. The reminder systems evaluated th was informed, and the doctor

A clinical nurse specialist led a A clicical nurse specialist led a of infection control commission, doctors, to the development allowed nurses to make decisions roper indications were not known and/or not justified. The nurses Removal Protocol.

\section{Discussion}

In the search for better evidence, we concluded that the articles present a high level of evidence for the answer to the matter being investigated. They are in between the levels I and II of evidence ${ }^{(4)}$, promoting a more consistent validity for the resolution of the problem.

The number of participants in the analyzed studies varied between 50 and 4,963. In two retrospective studies (11-12) what was defined was the time of development of the studies, and not the number of clients.

Although big difference between the number of participants in different studies, having groups with more than $2,000^{(6-7)}$, the results were similar in comparison to smaller groups. We determined that, despite the difference in the methodology applied, the results of the studies are analogous. In the majority of them, there was an intervention phase and a post-intervention one ${ }^{(6-7,9-10,13-14,17)}$. Some studies motivate the formation of nurses about the guidelines of prevention of CAUTI, revealing extreme importance in their duties $(9,11-15,17)$. 
Taking into account the obtained results, according to Figure 4, they all respond to the matter of the investigation: "What are the strategies health professionals use for implementing the Centers for Disease Control and prevention (CDC) guidelines for CAUTI prevention?", once they demonstrate the intervention of the health professionals in the implementation of different strategies for the response to the matter of CAUTI and obtaining effective results.

By making the audit document(15) - UCAM - based on scientific recommendation for the prevention of CAUTI, the nurses managed to improve the records under the manipulation done in the technique of vesical catheterization. The records, as indicators of vesical catheterization and evaluation of the necessity to keep the catheter, have motivated the removal of the catheters considered unnecessary (15-17). According to the guidelines of $C D C$ (2), the early removal of the urinary catheter contributes for the prevention of the infection associated to this device.

One of the strategies used by the nurses was to remind the doctor about the necessity of the urinary catheter ${ }^{(5-6,10)}$. The justification used by the nurses was based on appropriate indicators described on scientific evidence, concerning the need of the urinary catheter. In the cases in which the catheters were not removed, the duration of the catheterization decreased, so did the incidence of CAUTI.

The dominant strategy throughout the studies is the application of bundles of many formats in the prevention of CAUTI (7-9,11-14). The term bundle was developed by the Institute for Healthcare Improvement ${ }^{(18)}$ to describe a set of intervention, based on evidence and directed to the clients/population who are under inherent risks care. This set of intervention, when implemented together, originate significantly better results than those implemented individually(18). The bundle used were related to the insertion technique and the maintenance of the vesical catheter, to avoid the urinary catheter, and also, limiting its duration.

Another identified strategy was the creation of the algorithm for the maintenance of the urinary catheter, based on evidence, whenever really necessary ${ }^{(12,17)}$. On the other hand, when the indication for the usage of catheter was not present, it was removed after analysis with the doctor. With the application of the algorithm it was subjacent the daily evaluation of the necessity of the urinary catheter. Both studies allowed the reduction of the usage of the vesical catheter and the incidence of CAUTI.

With the purpose of assessing the necessity of the urinary catheter on clients, the impact of the daily participation of a nurse with management duties (nurse- led) was evaluated in the multidisciplinary visit and the assessment proposing the removal of the catheter (7). In this study, there is a decline of the usage and unnecessary usage of the vesical catheter. The decision making is based on evidence of the nurses in suspending the vesical catheterization. The nurses were based on the recommendation of scientific evidence for the making of protocols of performance in the prevention of CAUTI, from its insertion and maintenance, until the evaluation of the necessity of catheterization(9,13-14,16-17).

In summary, the health professionals, based on CAUTI prevention guidelines, present many methods of implementation, responding, in an efficient way, to this problematic. The attention during the procedure, handling of the vesical catheter, duration of the catheterization and staff training are of extreme importance (19-20). Determining the crucial and decisive role that the health professional play in the prevention and control of urinary infection associated to urinary catheter. The awareness of the professionals for this problematic is a fundamental starting point for this supported practice, seen in some studies $^{(9,11-15,17)}$ in which education was one of the tools for the starting point of this change.

The strategies applied in the implementation of guidelines have lessened the incidence of CAUTI, however, they appear in the literature in a disperse way. This review brings up knowledge, once it systematizes results of the practice and it allows the health professionals access to effective, up-to-date infection control strategies, with positive results in the quality of health care.

As limitations of this study, we highlight the process of selecting the sample done only by a reviewer and the usage of the nurs* descriptor on the research strategy. The critic analysis of the criteria on the series of studies by two reviewers would result better consistency in this review $^{(21)}$, as well as, the absence of the nurs* descriptor associated to the research to other professionals and, consequently, other strategies of practical implementation of international recommendation. At last, the selected sample for the review was of a reduced number and more studies are necessary to increase the number of strategic evidence of implementation, as well as its contribution for effective changes in care practice.

\section{Conclusion}

The intervention based on evidence can promote the evaluation of the necessity of urinary catheterization and removing the catheter when not necessary and allowing the reduction of the CAUTI rate.

In relation to the goal of this study and in summary, the main strategies of implementation of the guidelines 
were the performance of audition to the procedure, reminder systems for the assessment of the necessity of urinary catheterization and the implementation of bundles. The strategies found by the nurses to respond to this problematic were efficient, with the development of the health team, based on the prevention and control of the infection and the improvement of the safety of the person who seeks the health services and are put through this technique. In practice, policies should be implemented to promote the early removal of the catheters, as well as, those that are not necessary, avoiding negative consequences to the client and the institution, namely the hospitalization period. This review, besides systematizing the strategies found by the health professional in the implementation of the guidelines in the prevention of CAUTI, opens the gates to new investigation on this area, as a starting point and gaps that can arise. It is important to emphasize the necessity of more studies about the intervention of health professionals in the performance and maintenance of the vesical catheterization technique and, consequently, in the prevention of CAUTI. The strategies described by them are not enough, they need health professionals awareness and motivation on this problematic and studies on other sections that can contribute to the prevention and control of infection associated to health care.

\section{References}

1. Instituto Nacional de Saúde Dr. Ricardo Jorge. Programa Nacional de Controle de Infeção. Recomendação para a Prevenção da Infeção do Trato Urinário. Lisboa; 2004. p.4.

2. Centers for disease Control and Prevention - HICPAC

- Healthcare Infection Control Practices Advisory Committee [Internet]. Guidelines for prevention of catheter - Associated Urinary Tract Infections; 2009 [Acesso 15 maio 2012]. Disponível em: www.cdc.gov/

3. Centre for Reviews and Dissemination - Systematic Reviews: CRD 's guidance for undertaking reviews in health care [Internet]. 2009 [Acesso 15 set 2012]. Disponível em: http://www.york.ac.uk/inst/crd/guidance.htm

4. US Department of Health and Human Services. Agency for Health Care Policy and Research [Internet]. Rockville, MD; Public Health Services. Agency for Health Care Policy and Research Publications; 1992 [Acesso 11 jan 2013]. Disponível em: http://www.hhs.gov/

5. Crouzet J, Bertrand X, Venier AG, Badoz M, Husson C, Talon

$D$. Control of the duration of urinary catheterization: impact on catheter-associated urinary tract infection. J Hosp Infect. [Internet] 2007 Aug [Acesso 29 maio 2012 ];67:253-7. Disponível em: www.ncbi.nlm.nih.gov/pubmed/17949851
6. Apisarnthanarak A, Thongphubeth $K$, Sirinvaravong S, Kitkangvan D, Yuekyen C, Warachan B, et al. Effectiveness of multifaceted hospital wide quality improvement programs featuring an intervention to remove unnecessary urinary catheters at a Tertiary Care Center in Thailand. Infect Control Hosp Epidemiol. [Internet] 2007 Jan; [Acesso 26 set 2012];28(7):791-8. Disponível em: www.jstor.org/stable/10.1086/518453

7. Fakih MG, Dueweke C, Meisner S, Berriel-Cass D, Savoy-Moore R, Brach $N$, et al. Effect of nurse-led multidisciplinary rounds on reducing the unnecessary use of urinary catheterization in hospitalized patients. Infect Control Hosp Epidemiol. [Internet] 2008 Sep [Acesso 26 set 2012];29(9):815-9. Disponível em: http:// www.researchgate.net/publication/23168588_Effect_ of_nursled_multidisciplinary_rounds_on_reducing_ the_unnecessary_use_of_urinary_catheterization_in_ hospitalized_patients

8. Loeb M, Hunt D, O'Halloran K, Carusone SC, Dafoe N, Walter SD. Stop orders to reduce inappropriate urinary catheterization in hospitalized patients: a randomized controlled trial. J Gen Intern Med. [Internet] 2008 April [Acesso 10 out 2012]; 23(6):816-20. Disponível em: www.ncbi.nlm.nih.gov/pmc/articles/PMC2517898/

9. Weitzel T. To cath or not to cath? Nursing. 2008;38(2):20-1.

10. Elpern H, Killeen K, Ketchem A, Wiley A, Patel G, Lateef $O$. Reducing Use of Indwelling Urinary Catheters and Associated Urinary Tract Infections. Am J Crit Care. [Internet] 2009 Nov [Acesso $17 \mathrm{dez}$ 2012];18:53541. Disponível em: http://ajcc.aacnjournals.org/ content/18/6/535.full

11. Winter M, Helms B, Harrington L, Luquire R, Mcvay T, Rhodes, N. Eliminating Catheter-Associated Urinary Tract Infections: Part I. Avoid Catheter Use. J Healthcare Qual. [Internet] 2009 Nov [Acesso 20 set 2012];31(6):812. Disponível em: http://onlinelibrary.wiley.com/ doi/10.1111/j.1945-1474.2009.00049.x/abstract

12. Rhodes N, Mcvay T, Harrington L, Luquire R, Winter M, Helms, B. Eliminating Catheter-Associated Urinary Tract Infections: Part II. Limit Duration of Catheter Use. J Healthcare Qual. [Internet] 2009 Dec [Acesso 29 set 2012];31(6):13-7. Disponível em: http://onlinelibrary. wiley.com/doi/10.1111/j.1945-1474.2009.00050.x/ abstract

13. Gokula M, Smolen D, Gaspar P, Hensley S, Benninghoff $M$, Smith, M. Designing a protocol to reduce catheter-associated urinary tract infections among hospitalized patients. American Journal of Infection Control. [Internet] 2012 [Acesso 11 nov 2012];30:13. Disponível em: http://www.ajicjournal.org/article/ S0196-6553(11)01334-4/fulltext 
14. Oman K, Makic M, Fink R, Schraeder $N$, Hullet $T$, Keech $T$, et al. Nurse-directed interventions to reduce catheter-associated urinary tract infections. Am J Infect Control. [Internet] 2012 [Acesso 11 nov 2012];40:54853. Disponível em: http://www.ajicjournal.org/article/ S0196-6553(11)01014-5/fulltext

15. Dailly S. Auditing urinary catheter care. Nurs Standart. [Internet] 2012 Jan [Acesso 29 set 2012];26(20):3540. Disponível em: http://rcnpublishing.com/doi/ abs/10.7748/ns2012.01.26.20.35.c8884

16. Chen YY, Chi MM, Chen YC, Chan YJ, Chou SS, Wang FD. Using a criteria-based reminder to reduce use of indwelling urinary catheters and decrease urinary tract infections. Am J Crit Care. [Internet] 2013 Mar [Acesso 14 abril 2015];22(2):105-14. Disponível em: http:// www.ncbi.nlm.nih.gov/pubmed/23455860

17. Mori C. A-voiding catastrophe: implementing a nurse-driven protocol. Medsurg Nurs. [Internet] 2014 Jan [Acesso 14 abril 2015];23(1):15-21. Disponível em: http://www.ncbi.nlm.nih.gov/pubmed/24707664

18. Institute for Healthcare Improvement [Internet]. Using Care Bundles to Improve Health Care Quality. IHI Innovation Series white paper. Cambridge, Massachusetts; 2012 [Acesso 20 jan 2013]. Disponível em: www.ihi.org/

19. Balduino LSC, Gomes ATL, Silva MF, Vasconcelos QLD, Araújo RO, Torres G, Fatores de risco de infeção e agentes infeciosos associados ao cateterismo vesical: revisão integrativa. J Nurs UFPE on line. [Internet] maio 2013 [Acesso 14 nov 2013] 7:4261-8 Disponível em: http://www.revista.ufpe.br/revistaenfermagem/index. php/revista/article/viewFile/4054/pdf_2651

20. Ercole FE, Macieira TGR, Wenceslau LCC, Martins AR, Campos CC, Chianca TCM. Revisão integrativa: evidências na prática do cateterismo urinário intermitente/demora. Rev. Latino-Am. Enfermagem [Internet]. 2013 [Acesso 26 jun 2015];21(1):459-68. Disponível em: http://www.scielo.br/pdf/rlae/v21n1/ pt_v21n1a23.pdf

21. Urra Medina E, Barría Pailaquilén RM. A revisão sistemática e a sua relação com a prática baseada na evidência em saúde. Rev. Latino-Am. Enfermagem [Internet]. 2010 [acesso em: 26 Jun. 2015];18(4):82431. Disponível em: http://www.scielo.br/pdf/rlae/ v18n4/pt_23.pdf

Copyright $\odot 2016$ Revista Latino-Americana de Enfermagem This is an Open Access article distributed under the terms of the Creative Commons (CC BY).

This license lets others distribute, remix, tweak, and build upon your work, even commercially, as long as they credit you for the original creation. This is the most accommodating of licenses offered. Recommended for maximum dissemination and use of licensed materials. 